\title{
The first record of Agrimonia gorovoii Rumjantsev in Korea (Rosaceae)
}

\author{
Kyong-Sook Chung* \\ Department of Medicinal Plant Science, Jungwon University, Goesan 28024, Korea \\ (Received 30 May 2017; Revised 19 June 2017; Accepted 23 June 2017)
}

\begin{abstract}
The distribution of Agrimonia gorovoii Rumjantsev in Korea is verified in this study. The species, described as from Primorsky Krai in Russia, was found in Chungcheongnam-do, Gangwon-do, Gyeonggi-do, and Jeollabuk-do provinces and in Incheon, South Korea. The species is characterized by ten stamens, deeply serrated leaflet margins, and long horizontal pilose stems. A Korean name, Gorovoi-jip-sin-na-mul, for the species is newly given, and a taxonomic description of the species and key to four Korea native Agrimonia taxa are presented.
\end{abstract}

Keywords: Agrimonia, Agrimonia gorovoii, flora of Korea, Rosaceae

Agrimonia L. (1753) comprises about 20 species occurring mainly in temperate zones throughout North America, Central America, the West Indies, southern South America, Europe, Asia, and the southern parts of Africa (Hutchinson, 1964; Robertson, 1974; Kalkman, 2004; Chung, 2008; Kline and Sørensen, 2008). The genus is a perennial herb with rhizomes and yellow flowers on raceme inflorescences, characterized by interrupted pinnately compound leaves and hooked bristly epicalyx segments, and has the type species of $A$. eupatoria L. (Wallroth, 1842; Skalický, 1973; Kalkman, 2004; Chung, 2008) (Fig. 1). The basic chromosome number is $x=7$, and a range of ploidy levels has been reported (4x, 6x, and 8x) (Hara and Kurosawa, 1968; Iwatsubo et al., 1993; Kwon et al., 2005). Infrageneric classifications have been proposed based on epicalyx and leaf characteristics (Wallroth, 1842; Skalický, 1973), and some species such as A. pilosa Ledeb. and $A$. eupatoria have been used for medicinal and horticultural purposes (Dulger and Gonuz, 2004; Park et al., 2012). Recent molecular phylogenetic investigations consider the genus in subtribe Agrimoniinae, tribe Sanguisorbeae, supertribe Rosodae, subfamily Rosoideae (Eriksson et al., 2003; Potter et al., 2007).

In Korea, three Agrimonia taxa have been recognized: $A$. coreana Nakai, A. nippopnica Koidz., and A. pilosa Ledeb., (Chung and Kim, 2000; Choi, 2007). Previously, Park (1974) verified five taxa (A. pilosa, A. pilosa var. nepalensis (D. Don) Nakai, A. pilosa var. nipponica (Koidz.) Ohwi, A. pilosa var. coreana (Nakai) Liou \& Y. L. Chang, and A. pilosa f. davurica Nakai) in Korea, but most Korean botanists recognized two taxa (A. pilosa and A. coreana) (Lee, 1980; Lee, 1996; Lee, 2003; Lee, 2006). Flower and fruit sizes, stamen numbers, and leaf and stipule shapes provide diagnostic characteristics for each taxon (Chung and Kim, 2000; Choi, 2007). Agrimonia pilosa occurs throughout Eurasia, whereas A. coreana and A. nipponica occur in East Asia (Chung, 2008). In addition, A. pilosa is octoploidy, and $A$. coreana and $A$. nipponica are tetraploidy (Chung, 2008; Kwon et al., 2005). A. coreana grows only in mountain areas and flowers approximately one month earlier than the other two species in South Korea (Chung and Kim, 2000).

Agrimonia gorovoii Rumjantsev (1987) was first described from Primorsky Krai, Russia. He distinguished the species by deeply serrated leaflet margins, long horizontal pilose stems, and short-node rhizomes occurring in small populations in humid or swampy grasslands in Khasan (Rumjantsev, 1987) (Fig. 2). Herbarium specimens of $A$. gorovoii were collected in South Korea (Chung, 1999). The specimens resemble $A$. pilosa overall but have deeply serrated leaflets and long hairs on stems (Chung, 1999). However, Chung (1999) failed to identify the specimens and find natural populations of the specimens. To verify the distribution of the species in Korea, the original description, a type specimen, and herbarium collections from Korea were investigated. In addition, field surveys were conducted at the type locality in Russia and herbarium specimen

\footnotetext{
*Author for correspondence: kchung@jwu.ac.kr
} 

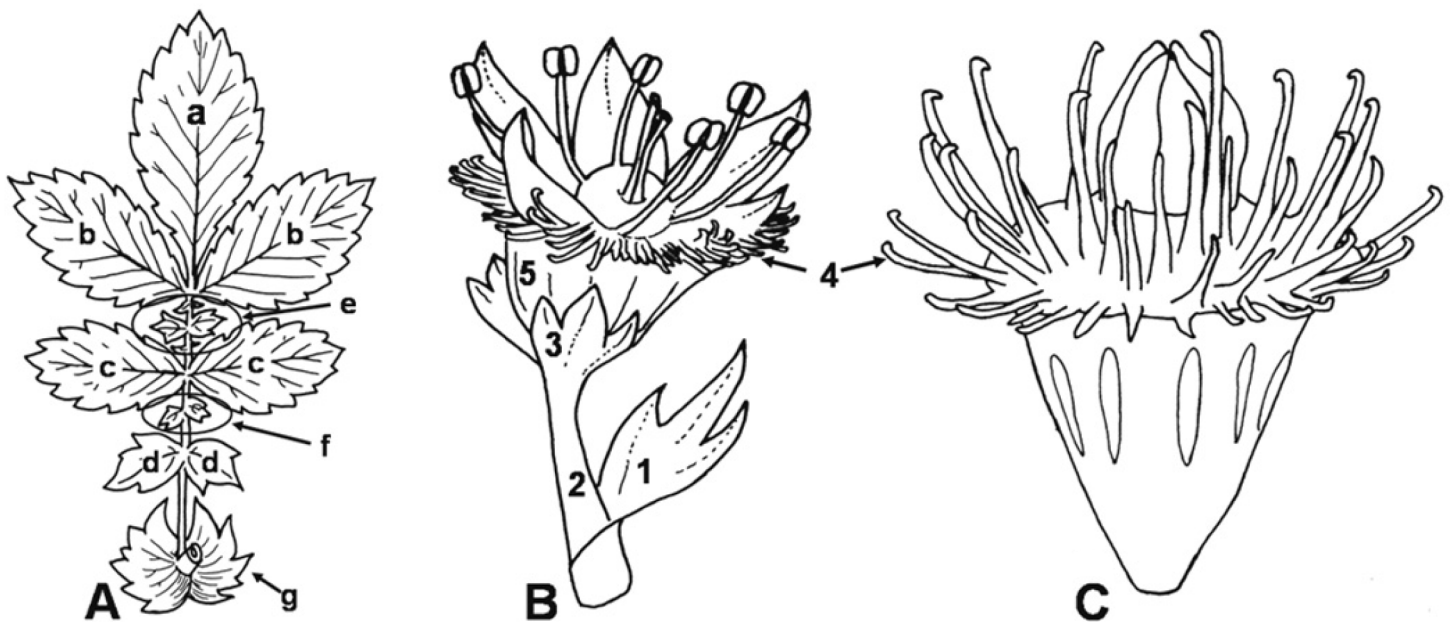

Fig. 1. Major vegetative and reproductive characters in Agrimonia adopted from Chung (2008). A. Interrupted pinnately compound leaf: a, terminal leaflet; $b-d$, lateral leaflets (b, 1st lateral leaflet; c, 2nd lateral leaflet; d, 3rd lateral leaflet); e, f, interstitial leaflets (e, 1st interstitial leaflet; f, 2nd interstitial leaflet); g, stipules. B. Flower (petals removed): 1, pedicle bracteole; 2, pedicel; 3, hypanthium bracteole; 4, epicalyx segments; 5, hypanthium. C. Fruiting hypanthium: 4, epicalyx segments.
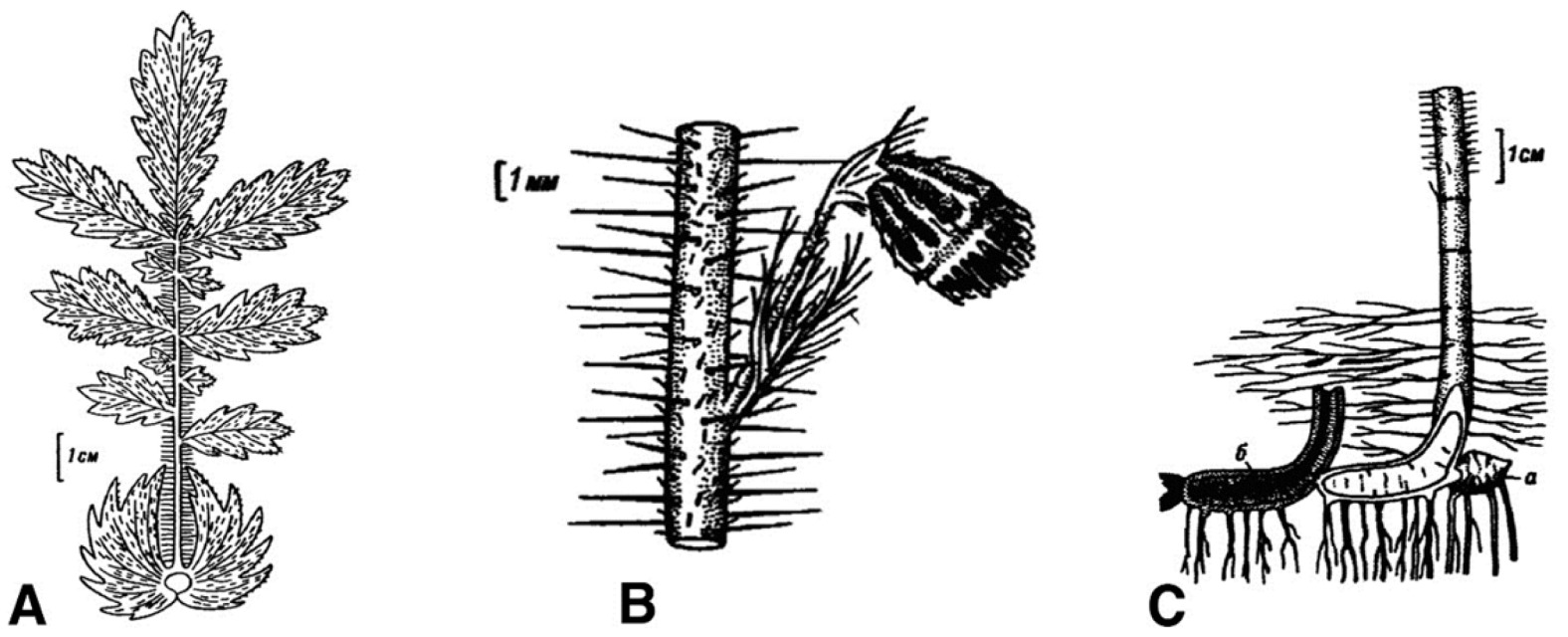

Fig. 2. Agrimonia gorovoii Rumjantsev adopted from Rumjantsev (1987). A. Pinnately compound leaf with stipules. B. Fruiting hypanthium. C. Rhizome: a, young shoot (next year); b, old shoot (last year).

collection sites in South Korea. The species is distinctive with deeply serrated leaflet margins and horizontal long hairs (Fig. 2). Recently, natural populations and additional herbarium specimens of the species have been found in Korea.

\section{Taxonomic Treatment}

Agrimonia gorovoii Rumjantsev, Bot. Zhurn. (Moscow \& Leningrad) 72: 1258, 1987.-TTYPE: Russia. Primorsky, Chassan (Khasan), 20 Aug 1986, P. G. Gorovoii \& S. Rumjantsev s.n. (holotype, MHA; isotypes, A![barcodeA00026008], B, L, LPLE, MO, MW, US, VLA).
Korean name: Gorovoi-jip-sin-na-mul (고로보이짚신나물).

Plant perennial herbs $40-150 \mathrm{~cm}$ tall. Roots fibrous on welldeveloped, short node rhizomes (15-25 mm long). Stems erect, rarely branched above, sparsely long horizontal brownish pilose (ca. $3 \mathrm{~mm}$ long). Leaves caulescent, alternate; leaflets (terminal and lateral leaflets) 7-9 in mid-caulis, sessile; terminal leaflets obovate, apex obtuse, base cuneate, margins deeply serrated, $4.3-4.8 \times 1.8-2.0 \mathrm{~cm}$, pilose scattered adaxially, pilose and glandular hairs abaxially; lateral leaflets obovate, apex obtuse, base cuneate, margins deeply serrated, largest ones smaller than terminal leaflets by $1 \mathrm{~cm}$ long, first interstitial leaflets 3 pairs 


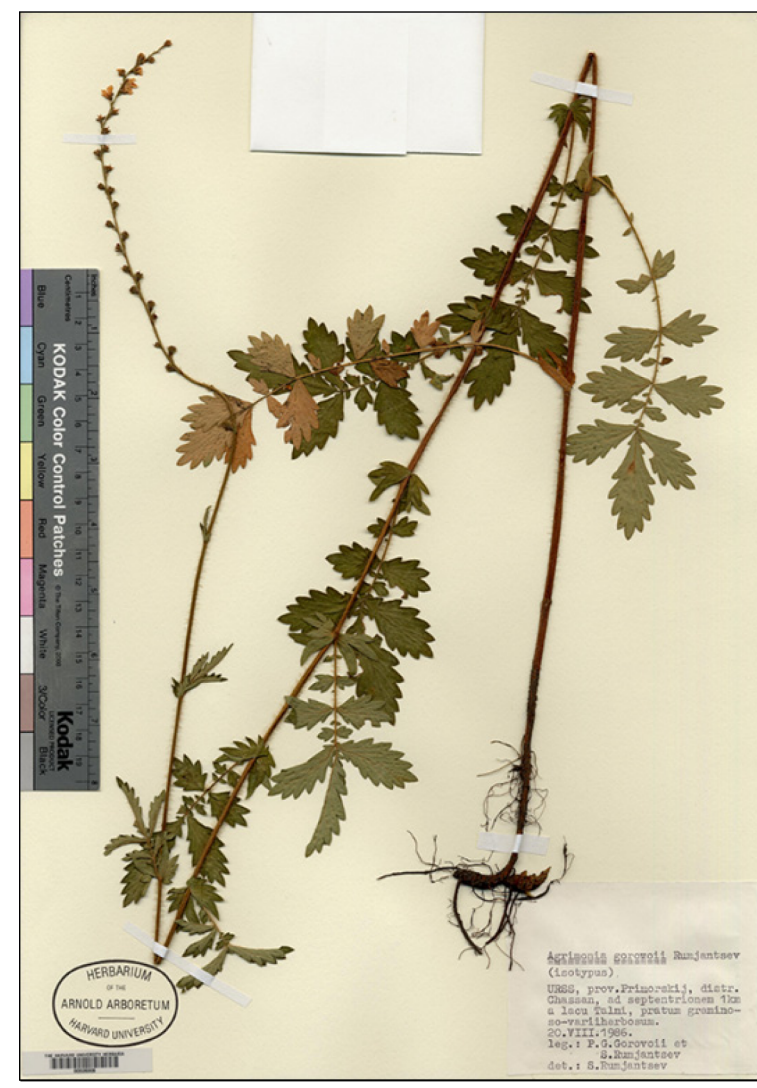

A

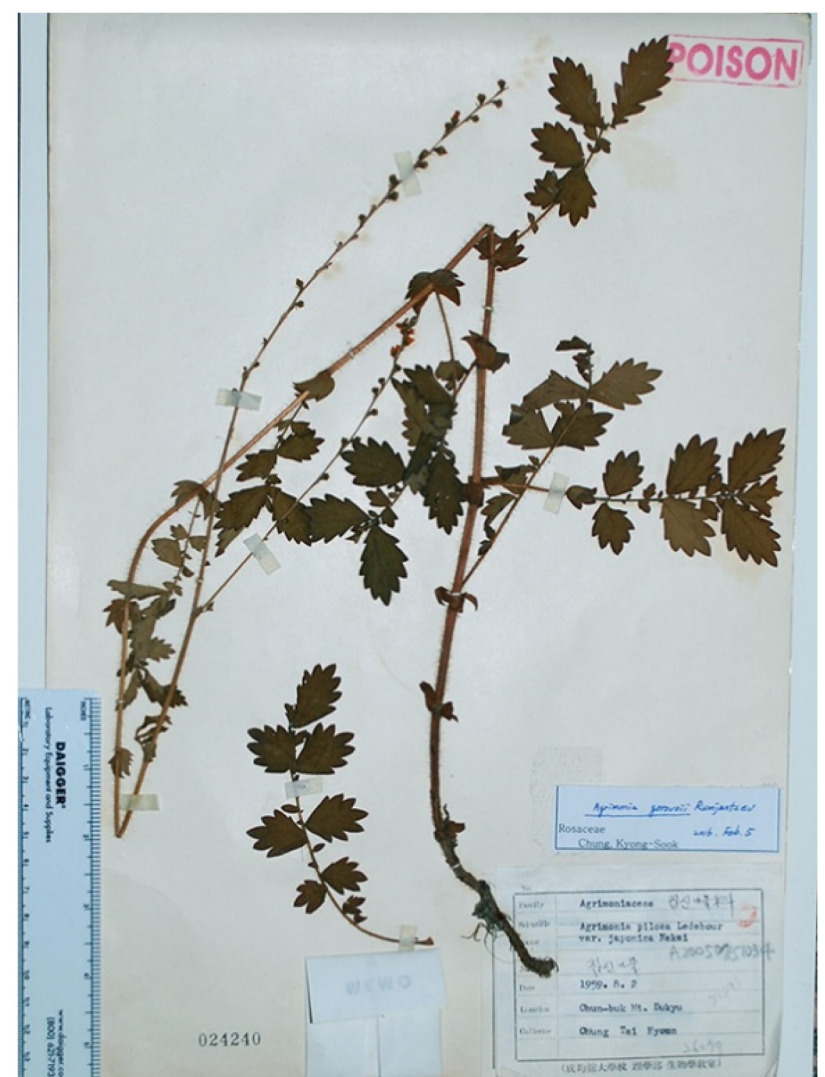

B

Fig. 3. Type and voucher specimens of Agrimonia gorovoii Rumjantsev. A. Isotype collected in Primorsky Krai, Russia, 20 Aug $1986, P$. G. Gorovoii et S. Rumjantsev s.n. (A). B. Voucher specimen collected in Jeollabuk-do province, South Korea, 2 Aug 1959, T. H. Chung 26079 (SKK).

with 2 different sizes, middle pair ones largest ca. $1 \mathrm{~cm}$ long, other interstitial leaflets usually 1 pair. Stipules flabelliformfalcate, horizontally spreading, regularly incised, ca. $2 \times$ $1.5 \mathrm{~cm}$. Inflorescences raceme, mainly terminal, loose (ca. 8 fully bloomed flowers $/ 5 \mathrm{~cm}$ long-inflorescence). Flowers ca. $13 \mathrm{~mm}$ across; pedicel 2.5-3 mm long; pedicel bracteoles 1, deeply tri-fid, hypanthium bracteoles 2, tri-fid; hypanthia obconical, pubescent and glandular; epicalyx segments numerous, persistent, cylindrical, cured at the tip, ca. $1 \mathrm{~mm}$ long; petals 5, golden yellow to yellow, obovate, ca. $5 \times 2.4 \mathrm{~mm}$; stamens 10 , persistent; filaments light yellow; anthers yellow, capitate, basifixed, dehiscence longitudinal; pistils 2, persistent, simple, free; ovaries pendulous, stylopodial present; locule 1, placentation base; styles 2, pale yellow, filiform, 2-3.5 mm; stigmas reniform, dilated. Achenes 1 or 2 per fruiting hypanthium; fruiting hypanthia semi-obconical or obconical, pilose and glandular, broadly sulcate, many ascending hooked bristly epicalyx segments on upper edges, $(4.38-) 5.23(-5.67) \times(3.12-) 3.78(-4.01) \mathrm{mm}$.
Flowering: Jun. to Sep.

Distribution: Russia (Primorsky Krai), Korea; sunny meadows and mountain trails.

Specimens examined: RUSSIA. Primorsky: Chassan (Khasan), 20 Aug 1986, P. G. Gorovoii \& S. D. Rumjantsev s.n. (A), 26 Aug 1986, P. G. Gorovoii \& S. D. Rumjantsev s.n. (MO), 17 Aug 2015, K.-S. Chung et al. s.n. (KH).

KOREA. Chungcheongnam-do: Gongju-si, Yogu-eup, Sindal-ri, Mt. Beophwasan, 24 Sep 2015, E.-H. Jung et al. Beophwa150709 (KB); Gangwon-do: Pyeongchang-gun, Daegwallyeong siheomjang, 20 Aug 1969, T.B. Lee s.n. (SNUA); Gyeonggi-do: Ansan-si, Danwon-gu, Seongam-dong, 20 Oct 2012. Lee \& Lee s.n. (KB), 23 Sep 2016, K.-S. Chung 4055, 4056 (KH); Incheon: Ganghwa-gun, Yangdo-myeon, Dojang-ri, Mt. Jingangsan, 19 Jul 2014, J.-H. Kim et al. Jingang140478 (KB); Jeollabuk-do: Mt. Deogyusansan, 2 Aug 1959, T. H. Chung 26079 (SKK).

Taxonomic note: This study expands the distribution range of $A$. gorovoii to Korea, increasing floristic diversity in the 
Korean Peninsula. The species resembles A. pilosa in leaf shape and fruiting hypanthium size, but is distinguished by deeply serrated leaflet margins and brownish horizontal long pilose stems (Figs. 2, 3). In common, natural populations in Russia and Korea are small and scatter with less than 10 individuals per population. They grow in sunny, open meadows or along mountain trails from 40 to $360 \mathrm{~m}$ in elevation. Isotypes of the species isotypes are deposited in a various herbaria, but the collection date of isotypes in MO and B herbaria differs from the holotype collection date of August 20. Verification of the type specimen is needed. Out of 20 species in the genus, four taxa occurs in Korea: A. coreana, A. nipponica, A. pilosa, and A. gorovoii. An Eurasian species, A. pilosa, is an octoploid, whereas Eastern Asian species, A. coreana and A. nipponica, are tetraploids (Chung, 2008). The ploidy level of $A$. gorovoii is unknown. Its small-sized and numbered populations require genetic investigations to develop proper conservation and management strategies in evolutionary as well as ethnobotanical aspects.

\section{Key to the species of Agrimonia in Korea}

1. Lateral leaflets 1-2 pairs in mid-caules, abaxial surface of leaflets densely glandular and tomentose

2. Flowers more than $10 \mathrm{~mm}$ in diameter, stamens 14 18, fruiting hypanthia more than $7 \mathrm{~mm}$ long, stipules flabellate …………A. A. coreana Nakai (산짚신나물)

2. Flowers less than $10 \mathrm{~mm}$ in diameter, stamens $5-10$, fruiting hypanthia less than $7 \mathrm{~mm}$ long, stipules falcate

\section{A. nipponica Koidz. (좀짚신나물)}

1. Lateral leaflets 3-5 pairs in mid-caules, abaxial surface of leaflets scatter glandular or pubescent

3. Leaflet margins dentate or serrate, stipule margins irregularly dentate, serrate, or entire, stem surfaces whitish non-horizontal pilose

A. pilosa Ledeb. (짚신나물)

3. Leaflet margins deeply serrate, stipule margins regularly incised, stem surfaces brownish, horizontal pilose …... …… A. gorovoii Rumjantsev (고로보이짚신나물)

\section{Acknowledgments}

The author thank Dr. Feruza Mustafina for the help with Russian references, and would like to thank the curators and staff members of the following herbaria for loans of herbarium specimens: Sung Kyun Kwan University (SKK), Seoul National University (SNUA), Chonnam National University Herbarium (CNU), National Institute of Biological
Resources (KB), and Korea National Arboretum (KH). The comments of two anonymous reviewers and Club $\mathrm{J}$ refined the manuscript.

\section{Literature Cited}

Choi, B.-H. 2007. Agrimonia L. In The Genera of Vascular Plants of Korea. Park, C.-W. (ed.), Academy Publishing Co., Seoul. Pp. 557-558.

Chung, K. S. 1999. A taxonomic study of the genus Agrimonia in Korea (Rosaceae) (Master's thesis). Korea University, Seoul. (in Korean)

Chung, K. S. 2008. A systematic study of genus Agrimonia (Rosaceae) (Doctoral dissertation). University of Oklahoma, Norman.

Chung, K. S. and Y. S. Kim. 2000. A taxonomic study on the genus Agrimonia (Rosaceae) in Korea. Korean Journal of Plant Taxonomy 30: 315-337. (in Korean)

Dulger, B. and A. Gonuz. 2004. Antimicrobial activity of some Turkish medicinal plants. Pakistan Journal of Biological Sciences 7: 1559-1562.

Eriksson, T., M. S. Hibbs, A. D. Yoder, C. F. Delwiche and M. J. Donoghue. 2003. The phylogeny of Rosoideae (Rosaceae) based on sequences of the internal transcribed spacer (ITS) of nuclear ribosomal DNA and the $t r n \mathrm{~L} / \mathrm{F}$ region of chloroplast DNA. International Journal of Plant Sciences 164: 194-211.

Hara. H. and S. Kurosawa. 1968. Cytotaxonomical notes on some Asiatic species of Agrimonia. Journal of Japanese Botany 43: 392-400.

Hutchinson, J. J. 1964. The Genera of Flowering Plants (Angiospermae). Vol. I. Dicotyledons. Oxford University Press, London, $516 \mathrm{pp}$.

Iwatsubo, Y., M. Mishima and N. Naruhashi. 1993. Chromosome studies of the Japanese Agrimonia (Rosaceae). Cytologia 58: 453-461.

Kalkman, C. 2004. Rosaceae. In The Families and Genera of Vascular Plants. Vol. 6. Flowering Plants - Dicotyledons: Celastrales, Oxalidales, Rosales, Cornales, Ericales. Kubitzki, K. (ed.), Springer, Berlin. Pp. 343-386.

Kline, G. J. and P. D. Sørensen. 2008. A revision of Agrimonia (Rosaceae) in North and Central America. Brittonia 60: 11-33.

Kwon, Y. J., M. R. Sul, J. K. An, C. H. Kim and B.-Y. Sun. 2005. Chromosome numbers of vascular plants of Mt. Baekdu and adjacent area in China. Korean Journal of Plant Taxonomy 35: 47-55.

Lee, T. B. 1980. Illustrated Flora of Korea. Hyangmunsa, Seoul. Pp. 446-447. (in Korean)

Lee, T. B. 2003. Coloured Flora of Korea. Vol. I, II. Hyangmunsa, Seoul, 545 pp. (in Korean) 
Lee, W. T. 1996. Standard Illustrations of Korean Plants. Academy Press, Seoul, Pp. 157-158. (in Korean)

Lee, Y. N. 2006. New Flora of Korea. I, II. Gyohaksa, Seoul, 559 pp. (in Korean)

Park, M. K. 1974. Keys to the Herbaceous Plants in Korea (Dicotyledoneae). Chungeumsa, Seoul, 593 pp. (in Korean)

Park, S.-H., Y.-B. Sim, Y.-J. Kang, J.-K. Lee, S.-S. Lim and H.-W. Suh. 2012. Effect of Agrimonia pilosa Ledeb extract on the Antinociception and mechanisms in mouse. Korean Journal of Physiology and Pharmacology 16: 119-123.

Potter, D., T. Eriksson, R. C. Evans, S. Oh, J. E. E. Smedmark, D. R. Morgan, M. Kerr, K. R. Robertson, M. Arsenault, T. A. Dickinson and C. S. Campbell. 2007. Phylogeny and classifica- tion of Rosaceae. Plant Systematics and Evolution 266: 5-43.

Robertson, K. R. 1974. The genera of the Rosaceae in the southeastern United States. Journal of the Arnold Arboretum 55: 303-332, 344-401, 611-662.

Rumjantsev, S. D. 1987. A new species of the genus Agrimonia (Rosaceae) from the Far East. Botanical Journal 72: 12581260. (in Russian)

Skalický, V. 1973. Amerikanische Arten der Gattung Agrimonia L. ser. Tuberosae ser. nova. Folia Geobotanica and Phytotaxonomica 8: 95-104.

Wallroth, C. F. W. 1842. Monographisher Versuch über die Gewächs-Gattung Agrimonia Celsi. Beitrage zur Botanik (Wallroth) 1: 1-66. (in German) 